\title{
MÜTAREKE DÖNEMINDE ITILAF DEVLETLERININ HAPISHANELER ÜZERINDEKI DENETIMI
}

\author{
TÜLAY ALIM BARAN*
}

Mondros Mütarekesi'nin imzalanması Osmanlı İmparatorluğu açısından bir dönemin kapandığına işaret eder. Bu dönem; içeride çok uzun zamandan beri varlığını devam ettiren İttihat ve Terakki Partisi'nin aktif Türk siyasetinden uzaklaşması, mütareke hükümlerinin keyfi uygulaması sonucunda ortaya çıkan belirsizlik, karışıklık, işgaller ve bütün bunlara karşılık Mustafa Kemal'in önderliğinde bağımsızlık ve egemenlik savaşının başlaması gibi birden çok gelişmeye tanıklık etmiştir. Mondros Mütarekesi'nin imzalanmasının ardından başlayan İstanbul'un fiili işgali, Osmanlı Hükümeti'ni birçok açıdan karışılığa sürüklemiştir. Başlangıçta bütün işgallerin geçici olduğu düşüncesi ile hareket eden ve bunu bu şekilde aktaran yönetim, bir süre sonra her açıdan kontrol altına alındığını görmeye başlayacaktIr. Bu makale içerisinde incelemeye çalışacağımız hapishaneler üzerinde İtilaf Devletleri'nin oluşturduğu kontrol, Mondros Mütarekesi'nin dördüncü maddesinde yer alan harp esirlerinin teslim edilmesine ilişkin maddeden yola çıkılarak gerçekleştirilmiş, ancak aşağıda örneklerini vereceğimiz üzere, bu söz konusu maddenin kapsamından hızla uzaklaşılan bir anlayışla uygulamaya konulmuştur. Çünkü hapishanelerde sadece mütarekenin dördüncü maddesi kapsamına giren kişilerin olup olmadığı araşturılmamıs, Osmanlı vatandaşları, yeni kurulan devletlerin vatandaşları, Yunan uyıuğundan olanlar ya da oldukları iddiasında bulunanlar çıkarılmaya başlanmıştır. Dolayısıyla işgal, bir boyutu ile hapishaneler üzerindeki kontrol ve müdahale kapsamında da yaşanmıştır.

Bu nedenle bu makale, İstanbul ve Anadolu Hapishanelerinin işgal yıllarındaki durumunu ortaya koymadan öte, Mondros Mütarekesi hükümlerinin İtilaf Devletleri tarafından nasıl yorumlandığına ve değiştirildiğine dair olan örneklerden birisini, hapishaneler bağlamında ele almayı amaçlamaktadır.

\footnotetext{
* Doç.Dr., Yeditepe Üniversitesi, Atatürk İlkeleri ve İnkılap Tarihi Enstitüsü.
} 
Hapishaneler üzerindeki denetim, Osmanlı kurumlarını hızla büyük bir karmaşanın içine sürükleyerek, yetki ve otorite sorunu yaşanmasına yol açmıştır. Hapishanelerin kontrolü konusunda başvurulan yöntemin keyfiliği bile, Mustafa Kemal'in var olan üç yöntemden, tam bağımsızlığı tercih konusundaki nedenlerinin haklılığını, bir kere daha ortaya koymaktadır.

İstanbul'un 13 Kasım 1918'de fiilen işgal edilmesinden bir süre sonra askerî komuta konusunda, Fransa ve İngiltere arasında problemler başlar ve İtilaf Devletleri 1920'den sonra karmaşık bir bürokrasi oluştururlar. Paris'teki Yüksek Konsey'in, askerî komutanların yanısıra yüksek komiserlerin atanmasına karar vermesi 1919 'da gerçekleşir. Üsküdar, İtalyan bölgesi olup, Eskişehir ve batı banliyöleri ise Fransızların kontrolündedir. Pera, Galata ve Şişli gibi yerler İngiliz bölgesi içinde bulunmaktadır. İtilaf Devletlerinin Kasım 1918'de İstanbul'daki temsilcilerinin İngiltere'den Sir Somerset Arthur Gough Calthorpe, İtalya'dan Kont Carlo Sforza ve Fransa'dan ise Amiral Amett olduğu görülmektedir. ABD'nin konsolusu ve komiseri G. Bie Ravndal'dır. Müttefik Orduların Doğu Cephesi Başkomutanı General Franchet d'Esperey 8 Ocak 1919'da İstanbul'a gelir. Amiral Calthorpe ve Kont Sforza ile Doğu Akdeniz'deki ABD deniz kuvvetlerinin komutanı Amiral Mark Lambert Bristol, Yüksek Komiser ünvanını alırlar. Müttefiklerin Londra'daki temsilcilerinin 3 Aralık 1918'de kabul ettikleri karara göre; İngiliz, Fransız ve İtalyan Hükümetleri, Türkiye'nin Avrupa parçasında garnizon kuran İngiliz Birlikleri ve onlara komuta eden general, General Franchet d'Esperey'nin komutası altında kalacak, General Milne'nin ordusunun geri kalan kısmı Kafkaslar'a veya herhangi bir yere aktarıldığında bu birlikler üzerinde General Franchet d'Esperey'nin komutası sona erecektir. Üç Müttefik Yüksek Komiseri işgali gerçekleştirme konusunda anlaştıkları zaman General d'Esperey bunun subaylardan oluşmuş bir Müttefikler Komisyonu tarafından yönlendirilmesini önerir. Ancak işgal, İngilizlerin komutası altında yürütülür. General Milne İngiliz askerlerine, Osmanlı Harbiye Nezareti ile Posta ve Telgraf Idaresini işgal ettirir. General d'Esperey daha sonra görevden alınarak yerine General Nayral de Bourgon atanır ve General Milne de General Charles Harington ile değiştirilir $^{1}$.

Müttefik denetimi İngiltere, Fransa ve İtalya Yüksek Komiserlerinin elinde bulunup bu denetim, Polis Komisyonu, Sağlık Komisyonu, Gıda

\footnotetext{
' Bilge Criss, İsgal Altonda İstanbul, İstanbul 2000, s. 95-98,100-102.
} 
Komisyonu, Cezaevi Komisyonu, Sansür Bürosu ve Telgrafların Denetimi, Levazım Komisyonu, Pasaport Bürosu, Donanma ve Ordu Komisyonu, Liman Denetimi olmak üzere çok sayıda komisyon eli ile yürütülmektedir ${ }^{2}$. Mondros Mütarekesi'nin 22. maddesi, Türk tutsaklarının Müttefik Devletler buyruğunda tutulması, askerlik çağı dışındaki Türk sivil tutsaklarının salıverilmesi konusunun ise göz önünde bulundurulmasını içermektedir. Bu makale kapsamında bizi ilgilendiren Mondros Mütarekesi'nin dördüncü maddesi ise müttefik savaş tutsakları ve gözaltında bulundurulan ya da tutsak olan Ermenilerin tümünün İstanbul'da toplanarak koşulsuz olarak teslim edileceğini kayda bağlamıştır ${ }^{3}$. Mütareke görüşmeleri sürerken Rauf Orbay, dördüncü madde konusunda, Rus Ermenilerinden olan savaş tutsaklarının yurtlarına döndüklerini ve tutuklular için de af çıkarıldığını ve bu nedenle maddeden Ermenilerle ilgili hükmün çıkarılmasını istemiştir. Ancak İngiliz ve Amerikan kamuoyunun bundan vazgeçmeyeceği söylenerek bu madde aynen bırakılmıştır. Daha da önemlisi Venizelos, Rumlar için de bir madde konulmamıs olmasından dolayı şikayet edince, anlaşmanın imzalandığını, fakat murahhaslara gerekli emirlerin verilebileceği söylenerek anlaşma dışı da rahatlıkla hareket edebileceklerini göstermişlerdir ${ }^{4}$.

Örneklerini vereceğimiz üzere zaten uygulama, söz verildiği gibi Yunan isteklerinin karşılanmasına da yönelik bir şekilde olmuştur.

Mütarekenin imzalanmasından sonra İstanbul'da İtilaf Devletlerinin bir taraftan kendi aralarındaki yetki sorunları ile uğraştıkları, diğer taraftan ise İstanbul üzerinde otorite kurma çalışmalarına hızla devam ettikleri görülmektedir. İngilizler, ilk önce 1 Şubat 1919 tarihinde İngiliz savaş esirlerine kötü davrandığını ileri sürdükleri kişilerin isimlerinden oluşan bir listeyi tutuklanmaları için Osmanlı İmparatorluğu'na vermiştir. Teslimi istenenler, bırakışmaya uymamak, bırakışmanın uygulanmasını önlemek, İngiliz komutan ve subaylarına küstahlık, tutsaklara kötü muamele vb. gibi değişik konularda suçlanmaktadırlar. Buna Osmanlı İmparatorluğu, hukuk devleti ilkesine aykırı olduğu gerekçesi ile olumsuz yanıt vermiştir. İzmir'in işgalinden bir süre önce Damat Ferit, Webb'i ziyaret ederek kovuşturma yapturmakta ve hüküm giydirmede zorluk çekildiğini ve bu nedenle de savaş ve tehcir sorumlularının Malta'ya sürülmesini istemiştir. Bir süre sonra Calthorpe Babıali'ye haber bile vermeden bir kısım tutukluları Malta'ya, bir

${ }^{2}$ William Wheclock Peet, “Kent Yönetimi”, (Ed. Clarence Richard Johnson), İstanbul 2000, s. 103.

${ }^{3}$ İsmail Soysal, Türkiye'nin Siyasal Andlaşmalan, I.Cilt (1920-1945), Ankara 2000, s. $12,14$.

${ }^{4}$ Yusuf Hikmet Bayur, Türk Inkılabı Tarihi, Cilı 3, Kısım 4, Ankara 1983, s. 749-750. 
kısmını ise Mondros'a göndermiştir ${ }^{5}$. Malta'ya yapılan sürgünlerin dışında bir diğer önemli uygulama, İtilaf Devletleri komiserlerinin İstanbul Hapishanelerine ilişkin olarak yaptıkları teftişler ve ardından bir kısım tutukluları salıvermeleridir ki bu konu bizim çalışmamızın esasını oluşturmaktadır.

Mondros Mütarekesi'nin dördüncü maddesi her ne kadar açıcça İtilaf Devletlerine mensup savaş esirleri, Ermeni esirleri ve tutukluların İstanbul'da toplanarak kayıtsız şartsız teslim edileceğini hükme bağlıyorsa da uygulama bunlarla sınırlı olmaktan uzak bir yapıda gelişmiştir. Adi suçlardan mahkum olanlar başta olmak üzere, düzensiz ve usulsüz, keyfi bir salıverme başlamış ve İstanbul büyük bir yetki kargaşası yaşamıştır.

Müttefiklerarası Kontrol ve Örgütlenme Komisyonu'nun güdümünde oluşturulan sistem çok sayıda alt komisyonu içermektedir. Müttefik Devletler, İngilizlerin başkanlığındaki mali komisyon ile müttefiklerin eşit söz sahibi oldukları Hapishane ve Besin Komisyonu gibi komisyonlar aracılığı ile çok yönlü olarak denetimi ellerine alırlar. Müttefiklerin işgalci olarak durumları resmileşmediği için yasal yollardan mahkeme kuramamaktadırlar. Alternatif tek adli sistem olan Konsolosluk Mahkemelerinin işlevi ise, kapitülasyonların tek yanlı olarak kaldırılmış olması nedeni ile sona ermiştir. Ateşkes olmasına rağmen Türkiye ile İngiltere arasındaki savaş hali devam ettiği için İngilizler, kendi uyrukları üzerinde Osmanlı mahkemelerinin yargı yetkisini kabul etmemektedirler. Ağustos 1919'da İngilizler Karma Mahkemelerin kurulmasını kabul ederler ancak, Müttefiklerarası mahkemeler oluşturulmasına Osmanlı Hükümeti'nin razı olmasını şart koşarlar. Ancak bu öneri reddedilir. Eğer bu kabul edilecek olunursa, bu mahkeme, sadece medeni hukuk ve ticaret anlaşmazlığına bakacağı için yetersiz kalacaktır ve ayrıca ceza davaları, suçluları mahkum edecek yasal yöntemlerden yoksun bulunan Müttefik polisinin yetkisi altında kalmıs olacaktur ${ }^{6}$.

\footnotetext{
${ }^{5}$ Sina Akşin, İstanbul Hükümetleri ve Milli Mücadele, İstanbul 1976, s. 155-156, 313. Ahmet Emin Yalman Malta'ya yapılan sürgünleri anlatırken İtalya Hariciyc Nazırı olan Komiser Muavini Sforza'nın buna ilişkin olarak şunlan söylediğini aktarıyor: "Tevkiflere Müttefikler Yüksek Meclisi rehineler toplamak niyetiyle karar vermiştir. İngilizlerin burada askeri kuvvet sahibi olmalanı dolayısıyla işi yürütmeyi tek başlarına üzerlerine almışlardır. Tevkif edileceklerin listesini de onlar yapmıslardır. Fakat tevkif edilip Malta'ya sürülenler herhalde her üç devletin mesuliyet ve teminat altında kalacaklardır." Bkz. Ahmet Emin Yalman, Yakm Tarihte Gördüklerim ve Geçirdiklerim, Cilt 2, Istanbul 1970, s. 59.

${ }^{6}$ Bilge Criss, a.g.e, s. 106-107, 236-237
} 
İstanbul'da, biri bütün yerli halk üzerinde denetim yetkisi olan Yerli Polis Örgütü ve diğeri Müttefik Polis Kuvveti olmak üzere iki ayrı polis ekibi bulunmaktadır. Müttefik Polis Kuvveti, yerli polisin maaşını düzenli alması ve kentin herhangi bir yerinde yerli polisin görevini ihmal etmesi durumunda görevden alabilmekte; yerlerine yeni kişilerin getirilmesi konusunda talepte bulunabilmektedir ${ }^{7}$. Hem askeri hem de sivil işleve sahip olan Müttefik Kuvvetler Polisi, kentteki bütün ulusların sıkıyönetim yasası hükümlerine uymalarını sağlamakla yükümlüdür ancak, yetkileri sadece Müttefik Devletler vatandaşları ile sınırlıdır. İtalyan, Fransız, İngiliz polisi kendi polis şeflerinin yönetimi altında olup, hepsi birden Müttefik Kuvvetler Polis Komisyonu Başkanı Albay Ballard'ın denetimi altında bulunmaktadır. Türk polisinin tutukladığı kişi önce en yakın polis karakoluna götürülür. Burada dava konusu komiser tarafindan dinlendikten sonra bölge merkezine gönderilip, duruşması yapıldıktan sonra, tutuklanan kişi, tevkifhaneye gönderilmektedir. Suriçi, Pera ve Üsküdar'da olmak üzere üç tane de tevkifhane vardır. Bu tutukevi veya hapishaneler aynı zamanda yerel cezaevi işlevi görür ve duruşma gününü bekleyenler, kısa süreli mahkumlarla genellikle aynı koğuşta tutulurlar ${ }^{8}$.

Hapishanelerin kontrolü vilayet merkezlerinde Valilere, livalarda Mutasarrıflıklara, kazalarda ise Kaymakamlıklara aittir. Sadece Üsküdar ve Beyoğlu mutasarrıflıkları dahilindeki hapishaneler İstanbul Valiliğine bağlı bulunmaktadır. Bunlar ile Tevkifhane-i Umumi ve Hapishane-i Umumi'nin her birinin ayrı birer müdürü olmakla beraber, bu müdürlükler problemlerini üstlerindeki kurum olan "Mebani-i Emiriye ve Hapishaneler İdaresi Müdüriyeti"ne iletmektedirler" .

Müttefik Kuvvetler Polisi'nin denetimi altında ise en az altı tane geçici hapishanenin bulunduğu görülmektedir. Bunlardan biri Suriçi'nde Düyunu Umumiye Binası yakınındaki hapishanedir ve müttefikler tarafından ortaklaşa kullanılmaktadır. İngilizler Galata Kulesi ile Galata gümrüğü yakınındaki Arap Han'da belli yerleri hapishane olarak kullanırlar ve ayrıca Müttefik Polisi Komuta Merkezi'nin altında Pera'daki eski Otel Kroecker'de daha kalıcı bir hapishane yapma hazırlığı içindedirler. Fransızların Suriçi'nde, Marmara yakınlarındaki Kumkapı'da hapishaneleri

\footnotetext{
${ }^{7}$ William Wheelock Peet, a.g.m. s. 103.

${ }^{8}$ Charles Trowbridge Riggs,"Yetişkinlerde Suç", İstanbul 1920, s. 281-282, 288-289.

${ }^{9}$ Mümin Yıldıztaş, Mütareke Döneminde Suç Unsurlan ve İstanbul Hapishaneleri, Basılmamış Yüksek Lisans Tezi, İstanbul 1997, s. 64.
} 
bulunmaktadır ${ }^{10}$. Bunların dışında bir de konsolosluk hapishaneleri vardır ve ceza davalarında kendi vatandaşlarının davalı olarak Türk mahkemelerinde yargılanmaları konusunda Türk Hükümetine ait olan hak, Mütarekeden sonra işlerliğini kaybeder. Bu hak bu tarihden sonra Konsolosluk Mahkemeleri tarafından kullanılmaya başlanır. Mütarekeden sonra "Hapishaneler muamelatına bakmak, fakat hiç bir hususa müdahale etmemek ve bir mahiyet-i idariyi haiz olmamak kaydiyla" Mütareke Komisyonunca hapishaneleri teftiş etmek üzere muhtelit bir komisyon oluşturulur ${ }^{11}$.

İtilaf Devletleri yetkilileri oluşturdukları komisyonlar aracılığı ile İstanbul başta olmak üzere, Osmanlı İmparatorluğu'ndaki çoğu hapishaneye yönelik çalışmalarını bir kaç yöntemle yürütmüştür. Bunlardan birisi yukarıda andığımız üzere, Teftiş Heyetleri oluşturarak hapishaneleri kontrol etmek, bir diğeri Osmanlı Hükümeti'nin değişik suçlardan gözaltına aldığı ya da tutukladığı hükümlü ve tutukluları belli bir nedene ve sisteme dayanmaksızın çıkarmak ve bu yolla yetki kargaşası yaratmak, ele geçen bahaneleri kullanarak eleştirme ve müdahale alanlarını genişletmek.

İtilaf Devletlerinin İstanbul'da her şeye karışmak için firsat kolladıkları günlerde, hapishane teftişi fikri oldukça önem taşımaktadır. İstanbul'daki Merkez Hapishanesi'nin feci koşullarını ortaya koyan rapora karşılık Londra'da duyulan sevinç de bunun göstergesidir. Böylece Türklerin yalnız başkalarını değil, kendilerini de yönetmekten aciz olduklarını gösterecek kanıt bulmuş olacaklardır. Nitekim Dışişlerinin Calthorpe'a bu tür raporların siyasi değerinin bulunduğu ve bu nedenle taşradaki subayların da firsat buldukça yerel hapishaneleri ziyaret etmelerinin önemli olduğuna ilişkin bilgi verdiği görülmektedir ${ }^{12}$.

İtilaf Devletleri Fevkalade Komiserleri 12 Ağustos 1919 tarihinde yaptıkları toplantıda, hapishanelerin teftiş edilmesi görevini Mütareke Komisyonu üyelerine vermeyi kararlaşturmış ve onlara her türlü kolaylığın gösterilmesini istemiştir. İstedikleri bilgilere ulaşmaları konusunda da yardımcı olunması ve bu komisyonun arzu ettiği saatte hapishanelere girebileceğine ilişkin durumun ilgili memurlara duyurulması ve yanlarına da bir görevlinin verilmesinin yararlı olacağı ilan edilmiştir. Hapishanelerin teftiş edilmesi işinin İtilaf Devletleri tarafından yapılacak olmasının yaratabileceği olası endişeyi gidermek üzere ise Adliye Nazırı, Dahiliye Nezareti'ne, aslın-

\footnotetext{
${ }^{10}$ Charles Trowbridge Riggs, a.g.m., s. 303-304.

${ }^{11}$ Mümin Yıldıztaş, a.g.t., s. 73, 88 .

${ }^{12}$ Sina Akşin, a.g.e, s. 110.
} 
da bunun içişlerine bir müdahale olmadığını ve meseleye hıfzıssıhha noktasından bakmak gerektiğini yazmıştır. Bu nedenle de hapishanelerin ıslahı ve mahkumların durumlarının araştırılmasına yönelik bu teftişlerin, insanlık adına yardımdan ibaret olduğunu düşünmüşlerdir ${ }^{13}$.

Hapishanelerin İtilaf Devletleri yetkilileri tarafından teftiş edileceğinin anlaşılmasından sonra değişik illere yazılan yazılarla görevliler bu durumdan haberdar edilmiş ve özellikle sağlık koşullarına olabildiğince dikkat edilmesi ve böylece herhangi bir eleştiriye ve itiraza meydan bırakılmaması istenmiştir $^{14}$. Teftiş Heyeti, İstanbul başta olmak üzere Hüdavendigar, Bilecik, İzmit havalisiyle Konya'ya kadar uzanan bir hat üzerinde bulunan hapishaneleri teftiş edeceklerdir. Bu teftişlerde kendilerine Hapishaneler Idare-i Umumiye Mümeyyizi Bekir Bey'in refakat etmesi kararlaştırılmıştır. Bekir Bey'e gönderilen 5 maddelik talimatta şunlardan söz edilmektedir: Öncelikle söz konusu heyetin yapacağı bu teftişin usule uygun olduğu belirtilerek, bu görevin yerine getirilmesi için mahalli birimler nezdinde girişimde bulunulması istenir. Usule ve kanuna uygun olmayan şekilde ortaya çıkan bazı hareketler, örneğin suçlunun tahliyesi gibi konularda, merkeze başvurmanın gerekli olduğu kanaatinin heyet üyeleri üzerinde uyandırılması da Bekir Bey'den istenmektedir. Bunun dışında acil olan ve ciddi bir paraya ihtiyaç duymayan eksikliklerin giderilmesi, özellikle sağlık ve temizlik için harcamaların yapılması, daha fazla giderler için de İstanbul'a haber verilmesi, tahsis edilen 2000 lira paranın harcandığı yerlere ilişkin makbuzların İstanbul'a dönüşte verilmek üzere tutulması ve hapishanelerin tamirato için keşif yapılması konusunda ilgili mahallin yetkililerine tebligat yapılması da talimatta yer alan diğer konuları oluşturmaktadır ${ }^{15}$.

Hapishanelerdeki olası eksiklerin giderilmesi, sağlık koşullarından gıdaya eleştiriye neden olabilecek her türlü konunun üzerine gidilmesi ve Heyete kolaylık gösterilmesi duyurularının ardından, öncelikle sağlık koşullarına ilişkin ilk adımların atılmaya başlandığını görülmektedir. Sağlık koşullarına verilen önem nedensiz değildir çünkü, Teftiş Heyeti'nin hapishanelerle birlikte hastahaneleri de ziyaret ettikleri görülmüştür.

Bir süre sonra yapılan bu teftişlerin ardından İngiltere, Fransa ve İtalya Yüksek Komiserleri tarafından imzalanmış ve Bab-ı Âli'ye gönderilmiş göz-

\footnotetext{
${ }^{13}$ Başbakanlık Osmanlı Arşivi, (BOA) Dahiliye Nezareti Mebani-i Emiriye ve Hapishaneler Müdüriyeti (DH.MB.HPS) Dosya No: 81, Vesika No: 34.

${ }^{14}$ Dahiliye Nezareti Şifre Kalemi (DH.ŞFR), 105/51 ve 104/270.

${ }^{15}$ DH.MB.HPS, 81/65.
} 
lem sonuçları ortaya çıkmaya başlar. Anadolu'da on üç hapishaneyi kapsayan teftişin sonucu açıklanmıştır. Önce genel olarak gözlenenler yazılmış ve daha sonra bütün gezilen Anadolu hapishanelerine ilişkin olarak tek tek açıklama yapılmıştır. 9 maddede toplanan genel sorunlara ilişkin olarak; öncelikle hapishanelerin ve tutukluların pis olduğu, sadece ekmek yedikleri oysa nizamname gereğince sebze, et ve diğer gıdaların da verilmesinin gerekli olduğu belirtilmiştir. Bir diğer sorun hükümlü ve tutukluların bir arada bulunması ve bazı yerlerde bunların ayrımı mümkün olduğu halde buna dikkat edilmemiş olması, çocukların büyüklerle birlikte tutulması, doktorun her gün gelmesi gerektiği halde uygulamanın böyle olmaması, mahkumların hükümete çok pahalıya mal olmasına rağmen çalışmaması, oysa mahkum çocuklar başta olmak üzere bunlara bir sanat öğretilmesinin doğıu olacağı, hapishanelerin sıkça denetlenmemesi, mahkeme sisteminin bozukluğu, örneğin İzmit'te bir hakimin aynı anda üç değişik mahkemeye bakması gibi çok sayıda sorun ortaya konulmuştur. Bazı yerlerde erkekler ve kadınlar için ayı ayı hapishanelerin yapılmamış olmasının üzerinde durulmuştur. Tutukluların mahkemeye geç çıkarılması da genel sorunlaı arasında bulunmaktadır. Küçük bir tamiratla veya yeni bir yerin inşa edilmesi ile çözümü mümkün olabilecek sorunlardan birisi de tutukluların odalar içerisinde yıkanması ve bunun da rutubete neden olması idi. Bu genel ifadelerin ardından Teftiş Heyeti, Anadolu'da toplam on üç hapishaneye ilişkin değerlendirmelerini açıklamıştır. Toplam mahkum sayısı ve bunlardan kaçının kadın, kaçının erkek olduğu bilgilerinin yanı sıra ayrı ayrı tutuklu ve hükümlü sayısı raporlarında belirtilmiştir. Buna göre örneğin Bursa Hapishanesi'nde mahkum sayısı çok fazla bulunmuş, Adapazarı Hapishanesi havadar ve gerek kadın, gerekse erkek için kapasite olarak uygun görülmüş, anneleriyle kalan çocuklara süt verilmesi için Vali Bey'in girişimlerde bulunduğu yazılmıştır. İzmit Hapishanesi'nin ayrı binada tutulan kadın hapishanesi iyi bulunmuş, Bilecik Hapishanesi idaresi ve temizliği açısından çok beğenilmiş ve hatta bütün hapishanelerin böyle olması dileğinde bulunulmuştur. Bu hapishanede bulunan iki frengili hasta Bilecik'te hastahane bulunmaması nedeni ile Bursa'ya gönderilmiştir. Eskişehir Hapishanesi kalabalıklığına ek olarak firar olayları nedeni ile de dikkat çekmiştir. Aynı şekilde Afyonkarahisar hapishanesinden de firarlar görülmüştür. Bunların dışında raporlardan ortaya çıkan sonuç, kadın hapishanelerinin daha temiz olduğunu ortaya koymakta, ama genel olarak döşemele- 
rin eskiliği, rutubet, güvenlik sorunu, izdiham, hapishane müdürlerinin görevlerini ihmal etmeleri gibi sorunları içermektedir ${ }^{16}$.

İtilaf Devletleri temsilcileri hapishaneleri gezerek belirledikleri eksikleri İstanbul'a bildirmekte, Hükümet söz konusu şikayetlerin araştırılmasını ve giderilmesini ilgili yerlerden istemekte, ancak şikayete konu olan iller veya ilçelerdeki yetkililer ellerindeki bütçeden daha fazla olan talepler için para istemekten başka bir şey yapamamaktadır ${ }^{17}$.

İstanbul genelinde yapılan teftişlere gelince; buradan çıkan sonuçların bir kısmı sağlık koşullarına ilişkindir. Örneğin hasta bulunan bazı mahkumların hastahanelerde tedavi edilmelerinin gerekli olduğu, fakat Bab-1 Âli'nin ancak mahkumların rızası ile hastahanelere gönderileceklerine ilişkin kesin emrinin bulunduğu ifade edilmektedir. Yine söz konusu heyetten gelen ve Hükümetin dikkatine sunulan raporda; ziyaret edilen Üsküdar hapishanesinin iki tuvaletinin de yıkık olduğundan şikayet edilmiştir. Aynı şekilde Polis merkezinde bulunan nezarethanenin küçük odasında da hırsızlık suçundan tutuklanmış dört kişinin bulunduğu ve bunların burada 24 saatten fazla tutulmaması gerektiğine dikkat çekilmiştir. İstanbul Merkez Hapishanesi hastahanesinin ancak beş altı hastayı alabilecek kapasitede olmasına rağmen, odaların birinde on kişinin bulunduğu görülmüştür. Bu kalabalığa karşı getirilebilecek yer yokluğu mazereti ise, heyet tarafından boş odaların bulunduğunun belirlenmiş olması nedeni ile en baştan devre dışı bırakılmıştır. Ziyaretleri sırasında Hastahane müdürü, muavini ve doktorun da olmadığını rapor etmişlerdir. Askeri hapishanenin de aynı koşulları taşıdığı ifade edilmiş ve hastalıkları nedeni ile ya evlerine ya da hastahaneye nakledilmesi gereken hastaların isimleri tek tek yazılmıştır ${ }^{18}$. Sultanahmet'te bulunan hapishane kalabalık olmasının yanı sıra bulaşıcı hastalı̆̆ı olan bazı mahkumların bulunması nedeni ile endişe yaratmaktadır. Galatasaray, Sultanahmet ve Üsküdar hapishanelerine dair ortaya çıkan gözlem sonuçları, genellikle kalabalık olmaları ve sıhhi olmamaları

\section{${ }^{16}$ DH.MB.HPS.M, $41 / 32$.}

${ }^{17}$ DH.MB.HPS.M, 41/32. Örneğin Aydın Vilayeti'ne yazılan bir yazıda temsilcilerin, tutukluların iaşeleri konusunda olumsuz gözlemde bulunduğu ifade edilerek, derhal bunun sağlanması ve şikayet nedeninin ortadan kaldırılması istenmiştir. DH.ŞFR, 97/163. Aydın Valisi tarafindan yazılan cevapta ise mahkumlara günlük ve haftalık olarak neler verildiği yazılmış ancak, daha fazlası için paraya ihtiyaç olduğu bildirilmiştir. DH.MB.HPS.M, 37/84. İstanbul'dan yazılan yazılar eksiklerin giderilmesi talimatına ilişkin olup, bunların düzeltilmesi için istenilen paranın gönderildiğine dair belgelere pek rastlanmamaktadır.

${ }^{18}$ DH.MB.HPS, 80/70. 
noktasında toplanmaktadır. Dile getirilen şikayetlerden yola çıkılarak değişik girişimlerde bulunulmuş ancak, örneklerini vereceğimiz üzere bir taraftan İtilaf Devletleri yetkilileri izdihamdan şikayet ederken, diğer taraftan hapishane olarak inşa edilmekte olan binaları işgal etmeye başlamışlardır ${ }^{19}$.

Osmanlı İmparatorluğu ile İtilaf Devletleri temsilcilerini bu anlamda karşı karşıya getiren konu, yeni hapishanelerin yapılmasına ilişkindir. Yeni inşaatların siyasi bir zorunluluktan kaynaklandığı ve bu nedenle de bütçeye konulması için Maliye Bakanlığı'na yazı yazıldığı görülüyor. Ancak ortaya çıkan gecikme, belgenin ifadesine göre "Düvel-i Mutelife Komisyonu'na verilen teminata karşı suitesir" yaratmaktadır. Olumsuzluklara meydan vermemek üzere bütçeye söz konusu tahsisatın konulması ve bunun Maliye tarafından kabul ettirilmesi bu anlamda büyük önem taşımaktadı ${ }^{20}$. İshak Paşa'da inşa edilmekte olan Tevkifhane binasının askeri mahkumlar için kullanılmak üzere Merkez Komutanlığı tarafından zorla işgal edilmesi ve bu işgal sırasında henüz tamamen bitirilmemiş olan binanın gördüğü zarar, zaten had safhada olan hapishane ihtiyacını arttırmıştır. Binanın henüz tamamen bitmemiş olması, tutukluların burada tutulabilmesi olanağını ortadan kaldırmaktadır. İnşaat için ambarlarda bulunan malzemenin, ambarların işgal sırasında yıkılmış olması nedeni ile durumunu belirlemek de bir hayli güçtür. Bu durumda bulunan hapishanenin bir an evvel tahliye edilmesi için İngilizlere başvurulur. Oysa İngilizler, bir taraftan İzmit'te bulunan tutukluların da İstanbul'a getirilmesini istemekte ve daha da önemlisi orada jandarma olmamasına rağmen gerekli olan görevli vermeyi de reddetmektedirler ${ }^{21}$.

İtilaf Devletleri yetkilileri, Mütarekenin uygulanmaya başlaması ile birlikte hırsızlık, cinayet gibi suçlar başta olmak üzere neredeyse bütün Hıristiyanları tahliye etmeye yönelik çalışmalarına, hapishanelerin içinde bulunduğu olumsuz fiziki koşulları, gerekçe olarak göstermişlerdir. Hapishanelerin ıslahı için çalışmalar yapılsa da hatta yeni hapishanelerin inşaatına başlanmış olsa da içinde bulunulan savaş koşulları nedeni ile her şeyi düzeltmek mümkün değildir ${ }^{22}$. Denetimi bütünüyle elinde tutan İtilaf Devletlerinin Osmanlı İmparatorluğu'nun mali ve idari koşullarını bilmiyor olması da elbette düşünülemez.

\footnotetext{
${ }^{19}$ DH.MB.HPS.M, $41 / 38$.

${ }^{20}$ DH.MB.HPS, 40/56,40/37.

${ }^{21}$ DH.MB.HPS, 107/40.

${ }^{22}$ DH.MB.HPS, 79/39.
} 
Yapılan teftişler sırasında mahkumlar da bazı şikayetlerini Teftiş Heyeti'ne iletirler. Bu şikayetler, Hükümete iletilmekte ve İçişleri Bakanlığı da söz konusu şikayetlere konu olan mahkumların durumunun araştırılmasını ilgililerden istemektedir. Bir kısım hükümlüler, ifadeleri alınmadan suçların üzerlerine yıkıldığını iddia etmektedirler. Böyle bir uygulamanın söz konusu olamayacağına dair açıklamalara rağmen, baskı nedeni ile soruşturmaların bir süre devam ettiği görülmektedir ${ }^{23}$.

Hapishanelerin koşulları İtilaf Devletleri temsilcilerinin eleştirmek ve müdahale etmek için firsat bulmasına yol açmaktadır. Özellikle koğuşların kalabalık olması yukarıda da değindiğimiz üzere, Teftiş Heyetlerinin problem yaratmasına neden olmaktadır. Bunu ortadan kaldırmak üzere Osmanlı İmparatorluğu'nun zaman zaman af çıkardığı görülmektedir. Örneğin 12 Aralık 1918 tarihinde Hapishane-i Umumi'de bulunan ve ceza süreleri içerisinde iyi halleri görülenler için Padişahın af çıkardığı göıülür. Yine aynı yıl içerisinde Tevfik Paşa Kabinesi zamanında bu tarihe kadar siyasi suçlardan tutuklu olanların affedildiği açıklanmıştır ${ }^{24} .1919$ yılında ise Merkez Vilayet Hapishanesi'nde bulunan ve yaşları onsekizden aşağı olan cünha (kabahat) suçundan tutuklu 9 kişinin affedildiği ilan edilmekte ve hapishanelerdeki izdihamı hafifletmeye yönelik bu affın kapsamına kimlerin girdiğinin belirlenmesi için komisyonların oluşturulduğu anlaşılmaktadır ${ }^{25}$. Son olarak 21 Eylül 1920 tarihli Meclis-i Vükela kararıla Hapishane-i Umumi'de bulunan ve yaşları kırkı geçen, vereme yakalanan, cezalarının 2/3'ünü tamamlayan bazı kişilerin affedildiği görülmektedir ${ }^{26}$.

İtilaf Devletleri Komiserlerinin Mütareke sonrasında Osmanlı Hapishanelerine yönelik müdahalelerinin bir boyutu ise, başta da belirttiğimiz üzere bir nedene ya da sisteme bağlı olmaksızın tutukluların serbest bırakılması bağlamında gelişmiştir. Devletin polisi tarafından tutuklanan ve değişik suçlardan mahkum bulunan kimi tutukluların serbest bırakılması ve bu konuda kendilerini bağlayacak hiç bir kuralın dikkate alınmamıs olması oldukça ilginçtir.

İngiliz Fevkalade Komiserliği tarafindan adi suçlardan dolayı Osmanlı güvenlik güçleri tarafından tutuklanmış olan bütün İngiliz tebasının, hakla-

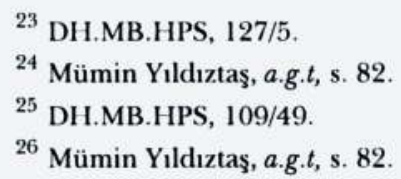


rında gereken kanuni işlemler yapılmak üzere İngiliz yetkililere teslim edilmesi isteği, Osmanlı Mebusan Meclisi tarafından kabul edilmiştir ${ }^{27}$.

İtilaf Devletleri uyruğundan olup Türk hapishanelerinde bulunanların tahliye edilmesi için "Müttefikin Hapishaneler Heyeti" adı altında bir heyet oluşturulmuştur. İngiliz, Fransız ve İtalyan yetkililerden oluşan bu heyete kolaylık gösterilmesi ve hapishaneleri ziyaret edecek olan bu kişilere birer hüviyet vesikası verilmesi de Hükümetlerinin ilgili temsilcileri tarafindan Osmanlı İmparatorluğu'ndan istenmiştir ${ }^{28}$.

İtilaf Devletleri kendi tebalarına ait olan veya kendi tebalarıyla ilişkili cezai ve hukuki konular için İstanbul Beyoğlu ve Üsküdar bölgesinde bir mahkeme oluşturmuşlardır ${ }^{29}$.

İtilaf Devletleri Polis Komisyonu bir süre sonra Polis Müdüriyet-i Umumiyesi'ne yazdığı yazıda; söz konusu devletlerin vatandaşlarının Osmanlı hapishanelerinde tutuklu bulunduklarına dair istihbarat aldıklarını, bunların kendilerine teslim edilmesi gerektiğini, eğer tutuklu bulunan kişinin uyruğu hakkında şüphe varsa bunun İtilaf Devletleri tarafından araştırılacağını belirtmişlerdir. Osmanlı tebasından olup da İtilaf Devletlerinin çıkarlarına tecavüz eden şahıslar müstesna olmak üzere hiç kimseyi hapsetmek niyetinde olmadıklarını ancak, 15 Nisan 1922 tarihinden itibaren makul bir nedene dayanmaksızın hapishanelerde İtilaf Devletlerine mensup birisinin tutuklu bulunduğunun anlaşılması halinde bütün memurlar hakkında şiddetli muamele yapılacağı açıklanmıştır. Daha da önemlisi bunların yeteri kadar uygulanıp uygulanmadığını kontrol etmek üzere Hapishane Heyeti'nin 15 Nisan tarihinden itibaren İstanbul mıntıkasında teftişte bulunacağı açıklanmıştır ${ }^{30}$.

Hapishanelerde tutuklu bulunan İtilaf Devletleri tebasına mensup kişilerin olup olmadığına ilişkin araştırma, çok kısa süre içerisinde sadece bunları kapsamaktan uzaklaşır ve bu noktadan itibaren de ciddi bir karışıklık yaşanmaya başlanır. Söz konusu karışıklık öncelikle doğrudan hapishanelere başvurulmaya başlanması nedeni ile yaşanır. Çünkü bu başvurular istenilen mahkumların mutlaka alınıp götürülmesi ile sonuçlanır ve öncesinde

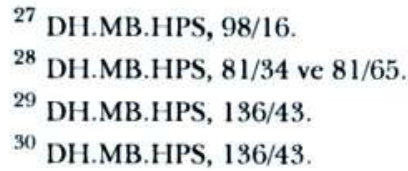


araştırma yapılmasına olanak bırakmaz. Karışıklıkla beraber şaşkınlık yaratan bir diğer konu ise çıkarılan mahkumların uyruklarına ilişkindir.

Başvurulan uygulamanın sadece İngiltere, Fransa, İtalya ve Amerika uyrukluları kapsamaması, Rus, İran, Yunan uyruklulara ve hatta bu iddiada bulunanlara ve Osmanlı uyruğunda bulunanlara da uzanması büyük sıkıntı yaratır. Aslen Bosnalı olan ya da Mütareke imzalandığında henüz kurulmamıs olan Lehistan, Yugoslavya, Çekoslovakya gibi ülkelerin vatandaşlarının da bu kapsama alınması ise tek kelime ile şaşkınlık ve yöntem sorunu yaratmışır ${ }^{31}$. İtilaf Devletleri yetkilileri herhangi bir suç ya da vatandaş ayrımı yapmaksızın hapishaneler üzerindeki denetim güçlerini değişik örneklerle ortaya koyarken, Osmanlı İmparatorluğu, İngiltere Fevkalade Komiserliğinin bu tahliyelere hoş bakmayacağını düşünmekte ve onlara haber vermenin doğru olacağına inanmaktadır ${ }^{32}$.

Başbakanlık Osmanlı Arşivi'nde bulunan çok sayıda belge, İtilaf Devletleri yetkililerinin hapishanelere girerek bazı tutukluları yanlarında alıp götürdüklerine dair bilgi içermektedir. Suçların çeşitlerine gelince; bu konuda kesin bir ayrımın gözetilmediğini ama belgelerdeki ifadelerden hırsızlık, gasb, cinayet, ihtikar, zorla ve hile ile senet imzalatmak, şekavet, sahte para, yaralama gibi değişik suçların bulunduğu anlaşılmaktadır. Sorunlardan bir tanesi bu mahkumların alınıp götürülmesi ve diğeri de bu mahkumların özellikle tatil olan Cuma günü götürülmesidir. Cuma günü yapılan başvurular, nöbetçi memurlardan başka kimsenin bulunmaması ve nöbetçi olarak bulunanların da yetkilerinin sınırlı olması nedeni ile sorunları arttırmaktadır. İtilaf Devletleri yetkililerinin Cuma gününün tatil olduğunu bilmemesi başlangıçta normal karşılanacak olsa bile, yanlarındaki genellikle Rum olan tercümanların bunu bilmemesi düşünülemez. Başvuruların arka arkaya özellikle Cuma gününe denk getirilmesi de bu düşünceyi kuvvetlendirmektedir. Oysa çıkarılmak istenen mahkumlar için doğrudan doğruya hapishanelere değil, Hapishaneler Müdüriyet-i Umumiyesi'ne başvurulması gerekmektedir. Dolayısıyla önce oraya başvuru yapılması ve oraya yapılan başvurunun ardından ilgili mahkumun talebinin 24 saat önce bildirilmesi ve bunun da Cuma günü dısında bir günde yapılması iç yazışmalarda defalarca dile getirilmiştir. Ancak İtilaf Devletleri temsilcilerinin Cuma günü yetkili bulamaması durumunda telefonla Polis Müdürüne ulaştığı ve bu telefonların ardından da mahkumların bırakıldığı görülmektedir.

\footnotetext{
${ }^{31}$ DH.MB.HPS, 136/43, 139/13, 130/67.

${ }^{32}$ DH.ŞFR, 98/132
} 
Ellerinde söz konusu mahkumların teslim edilmesini isteyen herhangi bir emir bulunmayan kişilere, Cuma değil örneğin Cumartesi günü başvurması söylenmesine rağmen ya telefonla ilgililere ulaşmak sureti ile ya da hapishane görevlilerinin itiraz edemeyeceği üst düzey İtilaf Devletleri askerlerinden birinin aracılığı ile her zaman istediklerine ulaşmışlardır ${ }^{33}$. Polis Müdürlüğü'nün bir hükümlü ya da tutuklunun teslimi hakkında hapishanelere emir vermesi, adliye kanunları, usul ve idare açısından hoş olmayacağı için bu durumda kalan Osmanlı memurlarının oldukça zorluk çektikleri anlaşılmaktadır ${ }^{34}$. İstedikleri mahkumların derhal tahliye edilmemesi durumunda hükümetin sorumlu olacağını bildiren yazılar da devleti ciddi sıkıntılar ile karşı karşıya bırakmışır ${ }^{35}$.

Silahlı olarak hapishanelere ve hastanelere giren İtilaf Devletleri yetkililerine karşı nasıl davranmak gerektiği konusunda da problemler yaşanmıştır. Silahı ile hapishaneye girmek isteyen İstanbul ciheti takım komutanına engel olunması, Fransız Cumhuriyeti Fevkalade Komiserliği tarafından sert bir dille eleştirilmiştir. Bu gibi şahısların silahlarını bırakmaksızın ve derhal içeriye alınması istenmiş, önceden izin almanın zaman kaybı olacağı ve esasen Osmanlı polisi ile birlikte genel çıkarlar için çalışıldığı hatırlatılarak Fransız komutana silahını teslim ettirmeye çalışan görevlinin de cezalandırılması istenmiştir ${ }^{36}$.

İtilaf Devletleri yetkilileri hapishanelere silahlı olarak gelip mahkumları rahatlıkla çıkarırken, Osmanlı İmparatorluğu'nun güvenlik için son derece gerekli olan silahlı gardiyan istihdamı konusundaki taleplerini ciddiye almamıştır. Hapishanelere silah sağlamak için İtilaf Devletleri Hapishaneler Komisyonu'nun onayını almak gerekmektedir ${ }^{37}$.

Daha sonra yapılan yazışmaların seyrinden, gardiyanların silahlandırıldığı anlaşılmaktadır. Ancak güvenliğe yönelik bu uygulamanın bu kez tamamen başka bir boyutta değerlendirildiği görülmektedir. Nitekim hapishanedeki ecnebi mahkumlardan bazıları tarafindan Ermeni Patrikliğine, Rum makamlarına ve Fransız, İngiliz, Yunan Komiserliği'ne hitaben bir mektup yazılmıştır. Mektupta silahlı gardiyanlar ve silahlı islam mahkumlar tarafından kendilerine bir kötülükte bulunulabileceğini düşündüklerini

${ }^{33}$ DH.MB.HPS, 98/50.

${ }^{34}$ DH.MB.HPS, 99/13.

${ }^{35}$ DH.MB.HPS, 109/22.

${ }^{36}$ DH.MB.HPS, 98/50.

${ }^{37}$ DH.MB.HPS, 83/51. 
ifade etmişler ve bu nedenle Hıristiyan hapishanelerine nakledilmeleri için kendilerini ziyarete gelenler aracılığı ile bu mektubu yazdıklarını, yapılan soruşturma sonucunda ifade etmişlerdir. Bu nedenle Emniyet-i Umumiye Müdürü tarafından mahkumların dışarıdaki insanlar ile mektuplaşmaları konusuna dikkat çekilmiş ve Hapishaneler Müdürlüğü'ne durum bildirilmiştir ${ }^{38}$.

Bir başka sıkıntı suçluların yapılan nakiller sırasında yabancı sefaret ve konsolosluklara firar etmeleridir. Bu türden firarlar ile suçluların cezalandırılması mümkün olmamaktadır. Bunu önlemek üzere nakil yollarının bu gibi sefarethanelerin bulunduğu yerlerin olmadığı noktalardan seçilmesi ilk akla gelen çare olarak görülmüştür. Ayrıca caydırıcı olması açısından onlara refakat eden görevlilerin de sorumlu tutulacağı kayda bağlanmıştır ${ }^{39}$. İtilaf Devletleri bu yolla ortaya çıkan firarlara ses çıkarmamakla beraber, diğer firar nedenlerini İmparatorluğu eleştirme vesilesi olarak kullanmakta ve bunu ortadan kaldırabilecek önerilere yanaşmamaktadırlar ${ }^{40}$.

Hapishanelere günü ne olursa olsun yapılan başvurular ve mahkumların teslim alınması, görevli memurların vermeme yönünde yaptıkları itirazlara rağmen, mütareke süresince devam etmiştir. Hapishanelerden Dahiliye Nezareti'ne tutulan zabıtlar gönderilmekte ve bu zabıtlarda kimlerin hapishaneye geldiği, mahkumun ismi, suçu, mahkumiyet süresi gibi bilgiler bulunmaktadır. İnzibat memuru, gardiyan ve başgardiyan imzası ile tutulan bu çok sayıda tutanaktan ortaya çıkan sonuç; genellikle Yunan tebasından olanların istendiği, Fransız ve İngiliz askeri yetkilililerin yanlarına tercüman alarak geldikleri ve yanlarında aynı zamanda bir Osmanlı polisinin bulunduğu, bazen de sadece tercümanları aracılığı ile mahkumları istedikleri yönündedir. Yapılan başvuruların kayıtlarda bulunan hemen hemen tamamına itiraz edilmiş ancak, bu itirazlara rağmen mahkumlar uyrukları ne olursa olsun mutlaka zorla alınıp götürülmüştür. Alıp götürdükleri mahkumlara ilişkin olarak da genellikle Fransızca bir makbuz bırakmışlardır. Bazen herhangi bir açıklama yapmadan bazen de İtilaf Devletleri tarafından yeniden yargılanacakları iddiası ile alınan bu şahısların her zaman

${ }^{38}$ DH.MB.IIPS, 165/15.

${ }^{39}$ DH.MB.IIPS, 102/30.

${ }^{40}$ Örneğin Dersaadet Hapishanesi'nde bulunan bazı mahkumların firarını araşırarak durumu rapor eden Jandarma Müfettiş-i Umumisi General Folon'a göre; kötü sağlık koşulları, yetersiz gardiyan sayısı, gardiyan maaşlarının azlığının yaraıtığı görevi umursamazlık ve haıtı az maaşla geçinemeyen gardiyanların mahkumların yardımı ile yaşıyor olması gibi bir dizi neden bu firarlarda etkili olmuştur. Bkz. DII.MB.HPS.M, 38/120. 
uyruklarını tesbit etmek de mümkün görünmemektedir. Evraklarında uyruklarına dair bir açıklama olmasa da bu mahkumların hepsinin Yunanlı oldukları iddiasında bulundukları görülmektedir. Bu iddiada bulunmayan ya da Rus olduklarını söyleyenlerin de rahatlıkla alınıp götürüldükleri görülmektedir. Hatta Osmanlı tabiiyetinde bulunanların da hapishanelerden çıkarıldıkları rastlanan işlemlerdendir ${ }^{4 !}$.

Esas sıkıntı, İtilaf Devletleri vatandaşı olmayanların çıkarılmasından kaynaklanmaktadır. Durumun siyasi nezaketi bilinmekle beraber, görevlilerin üzerlerine aldıkları sorumluluk nedeni ile endişe içerisinde oldukları anlaşılmaktadır. Hapishaneler üzerindeki bu baskı ve Osmanlı memurlarının karşı karşıya kaldığı sıkıntılar bir çok yazışmaya yansımışır. Yazışmalardan ortaya çıkan sonuç, hapishane görevlilerinin kendilerini sıkışmıs bir durumda hissettikleridir. Belgelerin ifadesi ile bir taraftan devletin şan ve şerefine uygun davranı̧̧ içerisinde bulunma zorunluluğu, diğer taraftan aslında işgalin bir başka çeşidi ile sık sık karşılaşma problemi, yetkilerinin hiçe sayılması ve bir dayatma ile karşı karşıya kalmaları, görevlerini yapmalarını engellemektedir ${ }^{42}$.

Vali ne yapılması gerektiğini Dahiliye Nezareti'nden sormakta, Hapishane Müdürü, Hapishaneler Genel Müdürlüğü'ne başvurarak bir çare aramaktadır. Dahiliye Nezareti'nden Hariciye Nezareti'ne yazılan yazıda İngiltere, Fransa, İtalya ve Amerika vatandaşları hakkındaki davaların ertelenmesine karar verildiği ancak Yunanlılara yönelik de bir şey yapılmaması talebinin neden kaynaklandığının anlaşılamadığı ifade edilmiştir. Acele ile mahkumların çıkarılması, kimliklerinin ve uyıuklarının araştırılmasına firsat vermemekte, ayrıca mütarekeden sonra uyruk değiştirmiş çok sayıda kişinin bulunması da durumun tam olarak anlaşılmasını engellemektedir. Osmanlı vatandaşı olduğu kesin olmakla beraber Yunanlı olduğu iddiası ya da bahanesi ile mahkumlar alınıp götürülmektedir. Ayrıca ilginç olan bir diğer nokta, tutuklu ya da hükümlü olan çok sayıda Yunanlı bulunmasına ve bunların isimleri de İtilaf Devletleri tarafından bilinmesine rağmen hepsinin birden çıkarılmayıp tek tek şahısların istenmesidir. Bu hepsinin çıkarılacağı gibi genel bir uygulamanın düşünülmesini engellemekte ve kafaları karışurmaktadı̊ ${ }^{43}$. Ayrıca mahkumların birbirlerini teşvik ve tahrik etmeleri

${ }^{41}$ DH. MB. HPS, 139/18, 132/15, 136/43, 126/44, 126/37, 130/23, 132/22, 126/43, 133/19, 126/37.

${ }^{42}$ DII.MB.HPS.M, 39/27.

${ }^{43}$ DH.MB.HPS, 107/38. 
sonucunda topluca firar ya da isyan eğilimlerinin de ortaya çıktığı görülmektedir ${ }^{44}$.

Başlangıçta konuşulan teslimler, sadece İtilaf Devletleri tebasına mensup olanlar için geçerli olacaktır ve Osmanlı İmparatorluğu yetkilileri, bunun Yunan uyrukluları kapsamayacağını düşünmüşlerdir ${ }^{45}$. Değişik suçlardan tutuklu bulunan Rumlar özellikle İngilizler tarafından salıverilmekte ve bu durum "gerek tevkifhanelerin ve gerek jandarmanın ehemmiyet ve nüfuz ve selahiyet-i kanuniyesini tamamen münhal" bir hale getirmek şeklinde değerlendirilmektedir ${ }^{46}$. Yunanlı oldukları iddiasında bulunanlar veya gerçekten Yunan uyruğundan olanlar için, İtilaf Devletleri Komiserlerinin özel bir ilgisinin olduğu gözlenmektedir. Bu ilgi ve devlet üzerindeki baskı nedeni ile söz konusu kişilerin durumlarının yeniden gözden geçirilmesi için Dahiliye Nezareti'nin yazışmalar yaptığı görülmektedir ${ }^{47}$. Yunan tebasından olanların İstanbul Müttefikin Polis Kontrol Heyeti tarafından istendiğine ve bunların teslim edildiklerine dair incelediğimiz belgeler içerisinde çok sayıda örnek mevcuttur ${ }^{48}$.

Hapishanelerde mahkumların detaylı bilgilerinin yer aldığı künyeler bulunmaktadır ${ }^{49}$. Bir süre sonra mahkumların kimler tarafından teslim alındığı, kimler tarafından teslim edildiği gibi bilgileri içeren cetvellerin hazırlanması istenmiştir ${ }^{50}$. Böyle bir yönteme başvurulmasının nedeni olarak İtilaf Devletleri temsilcilerinin, başta da belirttiğimiz üzere, sadece kendi tebalarından olanları tahliye ettikleri ya da edecekleri açıklamalarına karşın, uygulamanın böyle olmadığına dair bir kanıt sunmak arzusu olduğu anlaşılmaktadır. Nitekim hazırlanan çizelgelerde bunu ispat edici örnekler mevcuttur. Yunanlı, Rus, Sırp, Karadağlı gibi değişik uyruklular içinde en çok Yunanlı ve Rus olanların alındığı görülür. Oldukça önemli oranda da Osmanlı uyruklu mahkumun İtilaf Devletleri tarafından alınıp götürüldüğü anlaşılmaktadır. Her ne kadar Ittilaf Devletleri kendilerine karşı suç işlememiş olan Osmanlı vatandaşlarına karışmayacaklarını ilan etmiş olsalar da mahkumların suçlarına bakıldığında bunun kapsamının böyle belirlen-

\footnotetext{
${ }^{44}$ DH.MB.HPS, 107/38.

${ }^{45}$ Dahiliye Nezareti Emniyet-i Umumiye Asayiş Kalemi, 45/27.

${ }^{46}$ DH.MB.HPS.M, $51 / 47$.

${ }^{47}$ Dahiliye Nezareti Umur-1 Mahalliye-i Vilayat Müdüriyeti, 158/69.

${ }^{48}$ DH.MB.HPS 129/18.

${ }^{49}$ DH.MB.HPS, 107/38, 139/18.

${ }^{50}$ DI I.MB.HPS, 139/18.
} 
mediği açıkça görülmektedir. 1338 (1919-1920) tarihinde düzenlenen cetvellerde İtilaf Devletleri tarafından alınan Osmanlı vatandaşlarının suçları, yaralama ve adam öldürme, hırsızlık, gasb, sahtekarlık vb. gibi değişik başlıklar altında toplanmaktadır ve bunların içerisinde görüldügü üzere İtilaf Devletlerine karşı işlenmiş herhangi bir suç bulunmamaktadır. Diğer uyruklara ve bunların içerisinde çoğunluğu oluşturan Rus ve Yunan uyruklulara işledikleri suç açısından bakıldığında ise cinayet suçu işlemiş olanların da bulunduğu görülmektedir ${ }^{51}$.

Yunanlıların herhangi bir hukuka dayalı olmayan, keyfi salıverilmelerine karşı İmparatorluğun öncelikle tavsiye ettiği şeyin protesto olduğu görülmektedir. Dahiliye Nezareti tarafindan Sadarete yazllan bir yazıda protesto dışında bir karar alınması ya da kanun çıkarılması gibi bir yola başvurmanın, bu işin kabul edilmesi anlamına geleceği ifade edilmektedir ${ }^{52}$. Dahiliye Nazırı, kanun dairesinde her türlü uyarıyı dikkate alabileceklerini ancak, bu tarz talepleri hoş karşılamayacaklarını ifade etmis $\S^{53}$ ve Hariciye Nezareti'nden Mütareke Komisyonu aracılığıyla ilgili görevlilerle bağlantıya geçmesini istemiştir ${ }^{54}$.

Dahiliye Nezareti kural dışı bu uygulamaların karşısında Mütareke Komisyonu'na bir muhtıra yazısı yazmıştır. Özellikle Yunanlılardan uyrukları$\mathrm{n} ı$ belirleyecek hiç bir belgenin elde olmaması nedeni ile örneğin Yalovalı ya da Anadolu'nun herhangi bir yerinden olan bir kişiyi de Yunanlı oldukları iddiası ile alıp götürmektedirler. Öncelikle dikkat çeken nokta yukarıda da değindiğimiz üzere tek tek bazı şahısların alınıp götürülmesidir. İkincisi bunların uyruklarının muhakkak araştırılması gereğidir. Bunların gerçekten iddia ettikleri uyrukta bulunup bulunmadığı belli değilken ve Osmanlı vatandaşı oldukları yolunda kayıtlar da bulunuyorken iddia ettikleri uyruktan oldukları kabul edilmektedir. Üçüncü olarak ise mütarekeden sonra çok sayıda kişi uyruk değiştirmiştir. Osmanlı vatandaşlığından başka bir devletin uyruğuna geçme işi ise genellikle Yunanlılık iddiasında bulunanlar tarafından yapılmaktadır ${ }^{55}$. Bu nedenle hükümlü ya da tutukluların uyruğu ile ilgili olarak İtilaf Devletlerinden birine başvurması ve başvurunun da kabul edilmesi durumunda önce uyruğunun belirlenmesi için araştırma

${ }^{51}$ DH.MB.HPS, 139/18.

${ }^{52}$ DH.MB.HPS, $132 / 13$

${ }^{53}$ DH.MB.HPS, 98/39.

${ }^{54}$ DH.MB.HPS, 98/50.

${ }^{55}$ DH.MB.HPS, 130/67, 136/43. 
yapılması ve bunun öğrenilmesinden sonra ona göre davranılması uygun bulunmuştur $^{56}$. Yunanlılık iddiasında bulunanların tutukluluk halleri ortaya çıkmadan uyruklarının araştırılması, tutuklanmasına karar verilenlerin mahkeme sonucuna kadar tutuklanarak İtilaf Devletleri tarafından Tevkifhane olarak değerlendirilen Kumkapi'daki yere götürülmeleri ve tutuklu bulunup Yunanlı olduğu iddiasında bulunanlar hakkında da acilen karara varılması gereği Valilikten Dahiliye Nezareti'ne yazılmışır ${ }^{57}$.

Ancak başta da belirttiğimiz üzere doğrudan hapishanelere yapılan başvurular, hükümetin ihtiyacı olan zamanı ortadan kaldırmakta ve zorunlu olarak mahkumlar teslim edildikten sonra yapılan işlemler bir şey ifade etmemektedir. Bir kere tahliye edilmiş bulunan Osmanlı vatandaşlarının bile yeniden tutuklanması, araya girecek olan Yüksek Komiserlikler nedeni ile oldukça güç olmaktadır ${ }^{58}$.

Hapishane işlerine bakmakla beraber hiç bir şeye müdahale etmeyecekleri ve idari bir nitelik taşımayacakları ilan edilmiş olan komisyonlara yönelik tepkiler, sadece yazışmalarda yer almış ve herhangi bir değişiklik yapılamamıştır. Herşeyin kağıt üzerinde bir kayda bağlandığı düşüncesine rağmen uygulamanın bu şekilde olmaması, söz konusu İtilaf Devletleri yetkililerinin nüfuzlarını kullanması ve yetki aşımı olarak görülmüştür ${ }^{59}$.

Dolayısıyla, mütareke yıllarında hapishanelere ilişkin olarak yaşanan karışıklıkların en önemlilerinden biri, yetki ve ilgili makam sorunudur. İtilaf Devletlerinin hapishanelere ilişkin uygulamaları Osmanlı bürokrasisini ciddi bir karışıklığa sürüklemiştir. Hapishanelerin yönetimi mülki görevden olup Hapishaneler İdare-i Umumiyesi tarafından yürütülmektedir. Dahiliye Nezareti mahkumların tutuklanması, salıverilmesi ve bunlara ilişkin hiç bir konuda yetkili kabul edilmemekte ancak, İtilaf Devletlerinin yaptığı başvurular üzerine şahısların çıkarılmasına izin vermektedir. Bu konudaki tek yetkili makamın Adliye Nezareti olduğu israrla hatırlatılmasına rağmen İtilaf Devletleri, yetkili makam aramak gibi bir sıkıntı yaşamadıkları için konu sürekli olarak karısmıştır. Adliye Nezareti kesinlikle mahkum çıkarılmamasını belirtmişse de gerek onun beyanlarına ve gerekse Hariciye Nezareti'nin bütün girişimlerine rağmen bu hal devam etmiştir. Hapishanedeki düzeni sağlamak için kanuni bir yöntem olmasa da en azın-

\footnotetext{
${ }^{56}$ DH.MB.HPS, $130 / 67$.

${ }^{57}$ DH.MB.HPS, $107 / 38$.

${ }^{58}$ DH.MB.HPS, 99/13.

${ }^{59}$ DH.MB.HPS, $110 / 6$.
} 
dan hapishanelerdeki görevli memurları sorumluluktan kurtarmak, mahkumların isyanı ile ortaya çıkan güvenlik sıkıntılarını aşmak gibi bir çok nedenden dolayı bir makamdan verilecek izinle hareket edilmesi teklif edilmiştir ${ }^{60}$.

Osmanlı bürokrasisinin içinde bulunduğu bu karmaşa İtilaf Devletlerinin işini biraz daha kolaylaştırmıştır. İstanbul Hükümeti değişik bakanlıkla$\mathrm{n}$ arasında yetkili makam bulma konusunda yazışmalar yaparken, İtilaf Devletleri Komiserleri kurdukları komisyonlar, atadıkları görevliler aracılı$\breve{g}_{1}$ ile Mütarekeye uysun ya da uymasın, eylemlerine devam etmişlerdir. Bu süreç, her alanda olduğu gibi bu alanda da İstanbul'un 1920 yılındaki resmi işgalinden önce yürürlükte bulunan bir işgal döneminin sancılarını göstermektedir. İlginç olan nokta, müttefik devletlerin gerçekte asla uygulamayacakları konularda verdikleri sözlerin doğru olduğuna inanılmıs olmasıdır. İngiltere'nin de içinde bulunduğu komisyonlar aracılığı ile hapishaneler bir taraftan denetlenip, bir taraftan mütareke dışı uygulamalar birbirini izlerken Osmanlı İmparatorluğu'nun duruma hıfzıssıhha noktasından bakmaya çalışması ya da salıvermelerin onların bilgisi dışında yapıldığını düşünmesi ancak ilginç yaklaşımlar olarak değerlendirilebilir. Protestonun ötesinde bir çözüm bulamamıs olması, bulmaya çalıştığı bürokratik çözümlerin sonuç üzerindeki etkisizliği, buna karşın olabildiğince süren müttefik denetimi, dönemi karakterize eden belli satır başlarıdır ve oldukça düşündürücüdür.

${ }^{60}$ DH.MB.HPS, 132/13. 